\title{
Disabled Children in the Context of Russian Digital Economy Challenges
}

\author{
Michail V. Firsov ${ }^{1}$ \\ Alexander S. Sarychev ${ }^{2}$ \\ Yanina V. Shimanovskaya ${ }^{3}$ \\ Svetlana N. Kozlovskaya ${ }^{3}$ \\ Anna G. Akhtyan ${ }^{3}$ \\ Natalia P. Konstantinova ${ }^{3}$ \\ ${ }^{1}$ Institute for Additional Professional Education of Workers for Social Services, Moscow, Russia \\ ${ }^{2}$ Northern State Medical University, Arkhangelsk, Russia \\ ${ }^{3}$ Russian State Social University, Moscow, Russia
}

Doi: 10.2478/ajis-2019-0021

\section{Abstract}

The digital society having gained quite a momentum in the Russian Federation in the recent decade has brought along some new trends in "problems-shaping" not only for the producing, but also for the nonproducing strata of the population. The new "non-producing classes" get formed in a situation of new historical conditions the coordinates of which cover the entire global world, and it can be spoken definitely that problems of the Russian society are determined, among other things, by trends of the "world information community", with the former being a part of it nowadays. The paper outlines the main vectors of the problem of socialization of the disabled children in the contemporary Russian society within the context of information economy forming. Particularities of integration of children having disabilities are shown in the logic of development of the world social inequality processes based on the "digital divide" approaches. Proceeding from the Russian statistical materials, some suppositions are made about possible negative development scenarios of the present-day cohort of children having functional limitations who can become outsiders of the digital revolution and man the strata of nonproducing classes if there are no state programs, education strategies, pedagogical personnel and focused work with parents.

Keywords: disablism, disabled children, ageism, IT penetration, underclass

\section{Introduction}

For the world information community, some trends are characteristic that are defined by analysts worldwide as a "digital divide" or "information abyss" and that currently determine the new condition of social inequality.

According to the foreign researchers, digital services not only determine but also "aggravate" the processes of social inequality and social isolation of people in the complicated interaction in the contemporary world (Wessels, 2013; Jaeger, 2011).

The digital divide dynamics in the global community is influenced by the following factors:

- ethnic background, age, gender, education level, social and economic preconditions and 
status;

- technological divide between regions of the world having different infrastructure levels;

- the knowledge divide for those having little access, poor qualification and small cultural assets for using digital resources (Wessels, 2013; Dijk, 2012a, 2012b).

The modern digital technologies are integrated into the system of social relations, they determine people's social functioning at all stages of their lives, including their social status and opportunities, and forming conditions for social inequality.

Hence, there is another approach to social inequality based on the "digital divide"; it consists in speaking about not so much the individuals' characteristics, rather than relations between them, and group distinctions into which the "digital relations are interwoven" (van Dijk, 2012a, 2012b).

Digital technologies affect processes of people's social functioning, and it is they that currently determine the processes of socialization and enculturation.

The entire segments of the public get excluded from the social service system on the ground that the society cannot eliminate certain barriers for users of the services (Watling \& Crawford, 2010).

Alongside with social and moral references, the "digital divide" has economic parameters, too. The Internet economy is currently developing in all countries of the world. According to analysts' estimate, in the USA, retail online sales amount to 145 billion dollars per annum (Crabtree et al., 2016).

Within the context of digital economy, the contemporary system of consumer behavior is formed on the basis of an established integral system of human dispositions relying on the accomplished synthesis of the cultural, social and economic assets that are the condition of the subject's using information and computer technologies (Po-An Hsieh et al., 2011).

In the era of digital technologies, ageism, sexism, disablism, and ethnism as the forms of public discrimination gain the shape of social inequality, human rights restriction, and negative attitudes of some social groups toward others.

\section{Literature Review}

According to researchers, in order to overcome negative consequences, including ones for this group of population, certain mechanisms are required that have to include shaping motivational skills, providing material conditions, developing special professional skills, which as a total has to contribute to bridging the "digital divide" (van Deursen \& van Dij, 2015).

However, the present-day Russian situation is far from solving these problems. On the one hand, here one can speak about the lack of targeted social policy in relation to integrating the disabled people into the professional community (Kozlovskaya et al., 2016; Tarman \& Chigisheva, 2017).

On the other hand, there are no approaches and concepts of early professional development of disabled children for integrating them into the professional space, let alone into the digital one.

Experts believe it is school that has to become one of the mechanisms for overcoming the "digital abyss", especially for the rising generation. This process incorporates both the abilities and skills of working with personal computers and various software and the understanding of the way information and communication technologies can help "expand their personal opportunities" (Ritzhaupt et al., 2013). All these attitudes have to blend seamlessly into programs of learning for special needs children at all stages of socialization.

Children with disabilities that were born at the beginning of this century will live in the digital society. According to analysts, the digital society will "be built on software" that tends to be updated. With regard to this, for the new generation, the ability to continuously update their instrumental digital skills becomes a part and parcel of social competence of the $21^{\text {st }}$-century person (Svalastog et al., 2017).

However, the Russian practice of education of disabled children and foreign studies show that either there is no implementation of specialized programs for teaching information and computer technologies specifically to children having disabilities at the scale of state projects, or there are some but they are available in the non-public sector as paid services, which is an additional economic load for families having children with disabilities (Mavroua et al., 2017). 


\section{Research Methodological Framework}

The objective of the research was to study the process of "disablism" as a discriminatory social factor at the early stages of development of people being the most relevant for the Russian society. The tasks of the research are as follows: studying the conditions of life of disabled children in the complete and incomplete families; analyzing the statistical data about disabled children's attendance of comprehensive schools; estimating the opportunities for integrating the children into the system of digital technologies. During the research, the following methods were used: dialectical method, deductive and inductive methods, the methods of analysis and synthesis, comparison and contrasting.

\section{Results and Discussion}

As the Russian statistics notes, the majority of disabled children in the Russian society attend comprehensive schools while a much smaller part of the children are tutored at home being registered with a particular comprehensive institution where they do not pay due attention to digital technologies.

With regard to this, this stable trend is characteristic both for the children coming from multichild families, complete and incomplete ones. As the official statistics data show, the trend has not gone down for the recent years.

In 2011, the respondents of integrated observation of the population's conditions of life noted their children go to comprehensive schools. The fact was recorded by $82,1 \%$ of the respondents, with it being characteristic both for the complete families $(81,2 \%$ of the surveyed ones) and for the incomplete families $(82,1 \%)$.

Meanwhile, children of this age, 9 to 15, who were tutored at home, amounted to $14,2 \%$ and $17,9 \%$ in the complete and the incomplete families, respectively (www.gks.ru, 2011).

It can be noted that the percentage of children who cannot study due to their condition of health was $3,0 \%$. Statistics shows such a situation was characteristic for children of the complete families (www.gks.ru, 2011).

With regard to this, it can be said that not all potential actors of the labor market will participate in it, within the digital economy included.

The situation development dynamics registers some change in 2016. The disabled children's attendance of comprehensive organizations remains at a rather high level, according to the survey of the respondents. It can be noted that certain changes have taken place against the general high percentage of attendance of comprehensive institutions among the children. With the quantity of children attending comprehensive schools having decreased by $10,1 \%$, and amounting as a result to $72,2 \%$, the percentage of children being tutored at home has gone up to $18 \%$.

Currently, the increase of the percentage of children who cannot study due to their health condition from $3 \%$ in 2011 up to $8 \%$ in 2016. On top of that, the percentage of children not attending comprehensive institutions for various reasons grew up to 1,8\% (www.gks.ru, 2016).

However, according to the data of the Ministry of Education and Science of Russia, in general, there is a stable trend of increase of the quantity of students - disabled children and ones having health limitations - at comprehensive institutions from 2011 up to the 2016/2017 academic year.

So, the percentage of disabled children studying at comprehensive institutions was $1,7 \%$ of the total quantity of all students of comprehensive institutions in 2011/2012, and in the 2016/2017 academic year, their quantity amounted to $1,8 \%$ of all attendances of comprehensive organizations by children aged 9 to 15 in 2011 (www.gks.ru, 2017).

A similar trend is observed for children having health limitations. In 2011, the percentage of them in the total quantity of students was $2,6 \%$ at comprehensive schools, while it was already $3,9 \%$ in the $2016 / 2017$ academic year (www.gks.ru, 2011).

A growth can be noted in the percentage of parents thinking the children have to be integrated into the system of the primary, secondary and higher professional education. So, in 2011 , the percentage of such respondents - parents believing their children needed the primary or secondary vocational education - was $17,9 \%$, of those stating they needed the higher education $-25,3 \%$, with 
$49,9 \%$ of parents having difficulty answering the question (www.gks.ru, 2011).

Nevertheless, the situation changed in 2016. 34,2\% of the parents believed their children had to get the primary or secondary vocational education in a compulsory way, but the opinions of the parents' cohort were divided as for the higher education. It was only $8,6 \%$ of parents who believed their children needed the higher professional education. Meanwhile, it can be noted that a reduction trend of the respondents having difficulty answering the question is outlined - their quantity has fallen down to $16,8 \%$ (www.gks.ru, 2016).

It has to be pointed out that the percentage of parents who are not oriented to continuing their children's learning in the system of professional education grew up to 40,4\% in 2016.

In particular, it is characteristic that this percentage is quite high too and reaches $44,5 \%$ in the complete families bringing up the disabled children. Almost half of the families of the respondents surveyed can be considered to see no prospects for further education of these children (www.gks.ru, 2016).

It can be noted that the parents' standpoint does not promote further integration of their children into the system of digital technologies; directly or indirectly, they contribute to the fact that the essential "digital skills" get no further development, even if they have been formed back at the schooling stage.

Studies show the divide can only be eliminated in the case when a subject forms strategic skills enabling the subject to achieve professional and personal objectives as well as skills of creating the content, through which certain plans and projects are carried out (van Dijk, 2012a, 2012b).

The trends having formed in Russia can be explained by the following causes.

First of all, there is no state program of lifelong education for disabled children and for children having health limitations, with their further inclusion into the professional retraining system at all levels.

On top of that, the very cohort of such potential labor resources at the comprehensive institutions is quite nuanced because in 2016, there were the following main groups of nosology among the $\mathrm{HL}$ children - the total of 173851 students:

- ones having musculoskeletal disorders - 14378 children,

- ones having developmental delay - 106915 children

- ones having mental retardation 35933 children (minobrnauki.rf, 2016).

Secondly, this is associated with a rather poor level of comprehensive training of such children. This is confirmed by certain data obtained from families of the learners - children having these functional particularities.

In particular, according to the data of selective monitoring of the quality and accessibility of services in the sphere of education, healthcare, social service, people's employment promotion, in the $2014 / 2015$ academic years, $28,3 \%$ of the respondents surveyed were completely satisfied with the work of comprehensive institutions as assessed by parents, with the figure amounting to $25,7 \%$ of the respondents in the urban settlements, and $36,7 \%$ - in the rural settlements (www.gks.ru, 2015). Meanwhile, in the 2016/2017 academic year, the percentage of parents satisfied with the work of comprehensive institutions completely had an almost twofold reduction, sinking so low as to $14,5 \%$ in the urban settlements, and to $13,9 \%$ in the rural ones (www.gks.ru, 2017).

Thirdly, the contemporary Russian programs for teaching children with disabilities, among them the computer-based training programs, ignore the particularities of nosologies of the children having disabilities (Jaeger, 2011; Riley et al., 2000).

Fourthly, as of today, there are no Russian scientific studies in the field of psychology of digital technologies and their impact on the development of cognitive particularities in children having disabilities in conditions of school. There is no base of evidence enabling one to assess the efficiency of digital learning programs within the school education, as it is observed in the contemporary Western studies (American Optometric Association, 1995; Margalit et al., 1987; Subrahmanyam et al., 2001).

As the contemporary foreign longstanding studies show, children even having no health limitations but left out from various forms of digital technologies have no advancement along the career ladder and occupy the lowest ranks in the social standing (Yu Cheung Wong et al., 2015). 


\section{Conclusion}

Thus, while at the comprehensive school, the Russian disabled children of today are in the situation of "digital inequality" studying in line with correctional curricula and ones not aimed at the future digital economy trends. Comprehensive schools "reproduce" a new underclass for whom the "digital abyss" will only grow years later, which will increase the load on new social programs in the not so distant future.

The contemporary challenges of digital economy form new social groups that cannot join in the public integration processes due to the health limitations they have. The "digital abyss" that is being expanded currently in relation to children having disabilities will prevent them from integrating into social institutions, finding their place within the market relations system further on. Such a situation will result in financial load on the social sector of the economy growing, with the quantity of children disabled since childhood increasing, too.

This load will get only higher in the long run, because what the society will get is the new strata of "underclass" which will be represented not only by the "grown-up disabled children" but also by their parents who have supported them throughout their life and who due to their age will not be able to join in the "digital economic relations" anymore.

Considering the "digital divide" problem in relation to children with disabilities, on a short-term horizon, what has to be thought through is the role of state programs, socialization institutions, as well as inclusive education programs which would outline specific steps for integrating the special needs children within the digital economy system.

\section{References}

American Optometric Association. Guide to the clinical aspects of computer vision syndrome (1995). St. Louis: American Optometric Association.

Attendance of comprehensive organizations by children aged 9 to 15 in 2011. (2011). Federal State Statistics Service. Retrieved from http://www.gks.ru/ on January 20, 2019.

Crabtree, A., Lodge, T., Colley, J., Greenhalgh, Ch., Mortier, R., \& Haddadi, H. (2016). Enabling the new economic actor: data protection, the digital economy, and the Databox. Pers Ubiquit Comput, 20, 947957.

Effects of social skills training for students with an intellectual disability (2016). International Journal of Disability, Development and Education, 42, 75-85.

Jaeger, P.T. (2011). Disability and the Internet: Confronting a Digital Divide. Lynne Rienner Publishers.

Kozlovskaya, S.N., Shimanovskaya, Y.V., Starovojtova, L.I., \& Sarychev, A.S. (2016). Efficiency of social and psychological assistance to adolescents with bronchial asthma. Human Ecology (Russian Federation), 12, 22-29.

Margalit, M., Weisel, A., \& Shulman, S. (1987). The facilitation of infonnation processing in leaming disabled children using computer games. Educational Psychology, 7, 47-54.

Mavroua, K., Meletiou-Mavrotherisa, M., Kärkib, A., Sallinenb, M., \& Hoogerwerf, E-J. (2017). Opportunities and challenges related to ICT and ICT-AT use by people with disabilities: An explorative study into factors that impact on the digital divide. Technology and Disability, 2963-2975.

Po-An Hsieh, J.J., Rai, A., \& Keil, M. (2011). Addressing Digital Inequality for the Socioeconomically Disadvantaged Through Government Initiatives: Forms of Capital That Affect ICT Utilization. Information Systems Research, 22(2), 233-253.

Riley, R.W., Hoileman, F.S., \& Roberts, L.S. (2000). E-learning: Putting a worldclass education at the fingertips of all children. The national educational technology plan. Washington, D.C: U.S Department of Education.

Ritzhaupt, A.D., Feng, L., Dawson, K., \& Barron, A.E. (2013). Differences in Student Information and Communication Technology Literacy Based on Socio-Economic Status, Ethnicity, and Gender: Evidence of a Digital Divide in Florida Schools. Journal of Research on Technology in Education, 45(4), 44-67.

Satisfaction with work of comprehensive organizations where disabled children studied in the 2014-2017 academic years. (2017). Federal State Statistics Service. Retrieved from http://www.gks.ru/ on January 20, 2019.

Subrahmanyam, K., Greenfield, P., Kraut, R., \& Gross, E. (2001). The impact of computer use on children's and adolescents' development. Journal of Applied Developmental Psychology, 22, 7-30.

Support for families having disabled children. The "Early assistance" program. (2018). "Foundation for support of children". Retrieved from https://fond-detyam.ru on January 20, 2019. 
Svalastog, A.L., Donev, D., Kristoffersen, N.J., \& Gajovic, S. (2017). Concepts and definitions of health and health-related values in the knowledge landscapes of the digital society. Croat Med J., 58, 431-435.

Tarman, B., \& Chigisheva, O. (2017). Transformation of educational policy, theory and practice in post-soviet social studies education (Editorial). Journal of Social Studies Education Research, 8(2), I-IV.

The information about special (remedial educational institutions for students, boarders having health limitations and recreational institutions of health resort type for children needing prolonged treatment as of the beginning of the 2015/2016 academic year. Section 7. The information about disabled children and $\mathrm{HL}$ children studying at standard classes. (2016). Retrieved from https://minobrnauki.rf/ on January 20, 2019.

The intention of parents to continue the education of children studying in educational institutions, under the age of 15 years in 2011-2016. (2017). Federal state statistics service. Retrieved from http://www.gks.ru/ on January 20, 2019.

The percentage of children with health limitations studying at comprehensive institutions in the total quantity of comprehensive institutions students (according to the data of the Ministry of Education and Science of Russia). (2016). Retrieved from http://www.gks.ru/ on January 20, 2019.

van Deursen, A.J.A.M., \& van Dij, J.A.G.M. (2015). Toward a Multifaceted Model of Internet Access for Understanding Digital Divides: An Empirical Investigation. The Information Society, 31, 379-391.

van Dijk Jan, A.G.M (2012a). A theory of the digital divide. In: M. Ragnedda \& G.W. Muschert (Eds.), The digital divide: the Internet and social inequality in international perspective (pp. 29-52).

van Dijk, J.A.G.M. (2012b). The Evolution of the Digital Divide. The Digital Divide turns to Inequality of Skills and Usage. In: J. Bus et al. (Eds.), Digital Enlightenment Yearbook (pp. 44-46). IOS Press.

Watling, S., \& Crawford, K. (2010). Digital Exclusion: Implications for Human Services Practitioners. Journal of Technology in Human Services, 28, 205-216.

Wessels, B. (2013). The reproduction and reconfiguration of inequality differentiation and class, status and power in the dynamics of digital divides. In: M. Ragnedda \& G. W. Muschert (Eds.), The Digital Divide The internet and social inequality in international perspective (pp. 18-20). New York.

Yu Cheung Wong, Kit Mui Ho, Honglin Chen, Donghui Gu, \& Qun Zeng (2015). Digital Divide Challenges of Children in Low-Income Families: The Case of Shanghai. Journal of Technology in Human Services, 33, 53-71. 